\title{
Medialden açık kama yüksek tibial osteotomisi tertibatı
}

\section{Medial opening wedge high tibial osteotomy device}

\author{
İran Esenkaya \\ Ortopedi ve Travmatoloji Uzmanı, Emekli Öğretim Üyesi \\ SANTE Tıp Merkezi, Ortopedi ve Travmatoloji Kliniği, İstanbul
}

Buluş, medialden açık kama yüksek (proksimal) tibial osteotomi ameliyatlarında kullanılmak üzere yeni bir Kirschner teli klavuzu, "U" formlu osteotomlar, açı göstergeli distraktör ve yükseklik koruyucu destek takozu uygulama cihazından müteşekkil tertibattır. Konuyla ilgili faydalı model dosyası paylaşılmıştır. Tasarımı yapılan Kirschner teli kılavuzu ile osteotomi hattı en az sürede skopi kullanılarak belirlenebilmektedir. "U" şeklindeki osteotomlar ile karşı (lateral) korteksin kesilmesi önlenmiştir. Açı göstergeli distraktör ile kontrollü distraksiyon yapılarak lateral tibial platoda eklem içi kırık ve karşı kortekste kırık oluşumu önlenmiştir. Distraktörün açı göstergesinden distraksiyon miktarı ölçülebilmektedir. Yükseklik koruyucu takozlar ile de yapılan distraksiyon korunarak plak uygulanabilmektedir.

Anahtar sözcükler: faydalı model; diz eklemi; proksimal tibial osteotomi; el aletleri; Kirshner teli kılavuzu; "U" şeklinde osteotom; açı göstergeli distraktör; yükseklik koruyucu takoz

\section{T. C. Türk Patent Enstitüsü'ne Faydalı Model Belgesi için Başvuru Bilgileri ${ }^{[1]}$}

Başvuru bilgileri Tablo 1'de gösterilmiştir. ${ }^{[1]}$

Tablo 1. Başvuru bilgileri[1]

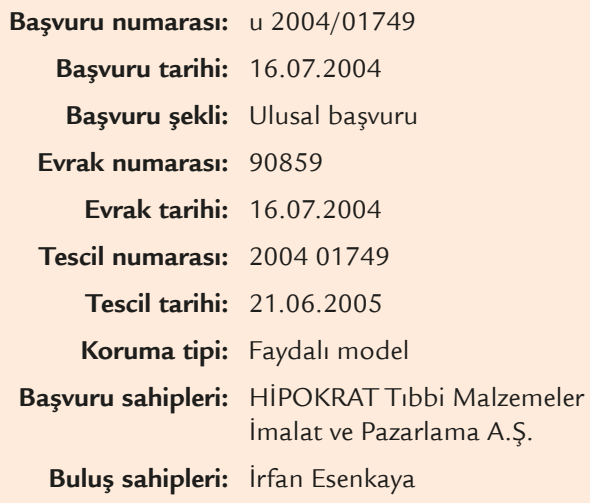

The invention is a device consisting of a new Kirschner wire guide, "U" shaped osteotomes, angle-scale distractor and a height conserving support wedge application device for use in medial opening wedge high (proximal) tibial osteotomy surgeries. The utility model file on the subject has been shared. With the Kirschner wire guide designed, the osteotomy line can be determined using fluoroscopy in the least amount of time. The cutting of the contralateral (lateral) cortex was prevented by "U" shaped osteotomes. Intraarticular fractures in the lateral tibial plateau and fractures in the contralateral cortex were prevented by performing controlled distraction with an angle-scale distractor. The distraction amount can be measured from the angle-scale of the distractor. Plate can be applied by preserving the distraction made with height protective wedges.

Key words: utility model; knee joint; proximal tibial osteotomy; hand tools; Kirshner wire guide; "U" shaped osteotome; anglescale distractor; height protective wedges
FAYDALI MODEL BELGESI - No: TR 200401749 Y[1]

\section{Teknik Alan ${ }^{[1]}$}

"Buluş, tıp alanında diz eklemi kaynaklı mekanik veya anatomik aks (eksen) bozukluğu yapan hastalıkların tedavisinde uygulanan cerrahi tekniklerden biri olan proksimal tibianın medialden açık kama osteotomisinde kullanılan kamalı destek plağının ${ }^{[2,3]}$ uygulanması esnasında kemiğin kesilmesi ve birbirinden uzaklaştırılması esnasında kullanılan yardımcı aletlerle ilgilidir. ${ }^{[1]}$ ”

\section{Tekniğin Bilinen Durumu ${ }^{[1]}$ \\ "Özellikle medial gonartrozda gelișen deformitelerde (şekil bozukluklarında) yüksek (proksimal) tibial osteotomi yaygın olarak kullanılan cerrahi bir tekniktir. Burada amaç, medi- alde yoğunlaşan ve kıkırdak aşınmasına neden olan dengesiz yükü osteotomiyle karşı tarafa (laterale) aktarmak ve medial taraftaki kıkırdak aşınmasının ilerlemesine engel olmaktır.}

- İletişim adresi: Prof. Dr. İrfan Esenkaya, SANTE Tıp Merkezi, Ortopedi ve Travmatoloji Kliniği, Kalamış, Kadıköy, İstanbul Tel: 0532 - 3218681 e-posta: iesenkaya@hotmail.com ORCID iD: 0000-0002-7321-0012

- Geliș tarihi: 29 Kasım $2020 \quad$ Kabul tarihi: 7 Aralık 2020 
Bu teknik lateralden kapalı kama osteotomisi, dome (kubbe) osteotomisi veya medialden açık kama osteotomisi şeklinde uygulanabilir. ${ }^{[1,3]}$

Açık kama osteotomisi “Hernigeu Ph., Medevielle D, Debeyre J, Goutallier D. Proximal tibial osteotomy for osteoarthritis with varus deformity, J Bone Joint Surg, 69-A, 332-354, 1987" yayını ile ifşa edilmiştir. ${ }^{[1,4]}$ Medialden açık kama osteotomisi genç ve aktif hastaların tek kompartmanlı varus osteoartritinde yaygın olarak kullanılmaktadır. ${ }^{[1]}$

Medialden açık kama osteotomisinde kemik yüzeyleri kesilerek birbirinden uzaklaştırılmaktadır. Uygulanan tekniklerde medialden laterale doğru kemik değiş̧ik açılarda kesilmekte (osteotomize edilmekte) ve önceden hesaplanan mevcut varus deformitesi oranında, osteotomize edilen kemik yüzeyleri düzeltilmek istenen açı kadar birbirinden uzaklaştırılarak değişik tespit materyalleri ile tespit edilmektedir. ${ }^{\left[{ }^{[1]}\right.}$ Başvuru sahibi tespit için, örneğin TR 2002 02021Y ile ifşa edilmiş (faydalı model belgesi alınmıs) olan kamalı destek plağı kullanmaktadır. ${ }^{[2]}$ Daha sonra distrakte edilerek açlan kemik boşluğu hastanın kendisinden alınan (otogreft) veya kadavra kökenli (allogreft) veya kemikle bütünleşme özelliğine sahip hidroksiapatit gibi boşluk doldurucu kemik veya benzeri yapılarla doldurulmaktadır. ${ }^{[1,3]}$

Uygulanan bir cerrahi tekniğinin başarılı olabilmesi için gerek uygulama esnasında, gerekse hastanın ameliyat sonrası takibinde karşılaşılan komplikasyonların önlenmesi veya en alt sınırlarda tutulması gerekmektedir. Yüksek (proksimal) tibial osteotomi tekniğini uygulayıcıları uyguladıkları yönteme göre değişik komplikasyonlarla karşılaşmışlar ve bunları ilgili yayınlarla belirtmişlerdir. Medialden açık kama osteotomisinde ise tekniği uygularken ameliyat esnasında en çok karşılaşılan komplikasyonlar lateral korteksin kırılması ve lateral tibia platosunda kırık oluşumudur. Bu komplikasyonlar "Spahn G. Complications in high tibial (medial opening wedge) osteotomy. Arch Orthop Trauma Surg, 2003, Sept. 30" adlı yayında detaylı olarak irdelenmiştir. ${ }^{[1,5]}$

Özellikle kapalı kama osteotomisinde karşılaşılan komplikasyonlar nedeniyle uygulayıcılar ameliyat esnasındaki tekniğe ve cerraha bağlı komplikasyonları en aza indirmek için çeşitli yardımcı aletler, kılavuzlar ve yöntemler geliştirmişlerdir. Bu yöntemler genellikle skopi veya röntgen altında uygulandığı için hem hasta, hem cerrah, hem de ameliyat ekibi x-ışınına maruz kalmaktadır. Yardımcı aletlerin uygun kullanımıyla radyasyon alımının da en aza indirilmesi olasıdır. ${ }^{[1]}$

Örneğin osteotomi hattının belirlenmesi için sadece tibianın medial korteksi üzerinden uygulanan pergel benzeri bir kılavuz kullanılmaktadır. Puddu ve ark. Arthrex'in "Opening Wedge Osteotomy, 2001-2002" kataloglarında söz konusu kılavuzu if̧sa etmişlerdir. Önce ekleme paralel bir tel medialden laterale doğru gönderilmekte, daha sonra tuberositas tibia üzerinden gidecek şekilde açı ve yön verilmiş ikinci bir tel gönderilmektedir. ${ }^{[1,6]}$ Ancak bu uygulamada tek seferde ve az ışın alarak Kirschner $(K)$ teli gönderilmesi mümkün olmamaktadır. ${ }^{[1]}$

Lobenhoffer ve Agneskirchner'in "Improvements in surgical technigue of valgus high tibial osteotomy. Knee Surg Sports, 2003 May; 11 (3): 132-138" ile ifşa edilen çaIışmalarında osteotomi sonrası distraksiyon için "spreaderchisel" adını verdikleri bir alternatif distraktör kullandıkları saptanmıştır. ${ }^{[1,7]}$ Söz konusu dokümanda cihazın teknik detayı ifşa edilmemiştir. Röntgen uygulaması da olmadığı için distraktörün osteotomi hattını nasıl etkilediği görülememektedir. Ancak bir yivli çubuk üzerinden üst parça uzaklaştırılmaktadır. Ancak parça adından da anlaşılacağı üzere ayırıcı osteotom olarak tasarlandığından yapısı kalındır. Çakılarak uygulanabilmekte ve kapalı iken $5^{\circ}$ den başlamaktadır. ${ }^{[1]}$

Kesi yüzeyine farklı derinliklerde uygulanan osteotomlar arasından distraksiyon yapıldığında lateral tibia platosuna uzanan kırıklar gelişebilmektedir. Bu tür durumlarda skopi eşliğinde iki ayrı osteotomu lateral kortekse doğru (bu sınırın $1 \mathrm{~cm}$ medialine kadar) uçları aynı hizada olacak şekilde gönderilmekte ve araya üçüncü ve gerekirse dördüncü osteotom uygulanarak distraksiyon yapılmaktadır. Ancak bu uygulama oldukça zor ve zaman kaybettiricidir. ${ }^{[1,3]}$

Mevcut çalışmalarda distraksiyon sonrası kama uygulamasına ilişkin Puddu plağının tasarımcısı G. Puddu uygulanacak plağın genişliği kadar açıklık bulunan ve bir ana gövde ile sapa tespit edilen iki kama kullanmaktadır. Söz konusu durum Arthrex'in "Opening Wedge Osteotomy, Tibial \& Femoral Opening Wedge Osteotomy System, 2001-2002” kataloglarında görülmektedir. ${ }^{[1,6]}$ Bu uygulamalarda kamaların geometrik formları nedeniyle kemik temas bölgesinden geriye kayma da gerçekleşebilmektedir. ${ }^{[1] "}$

\section{Buluşun Amaci ${ }^{[1]}$}

"Tekniğin bilinen durumundan yola çıkılarak buluşun gayesi, yeni yardımcı enstrümanlar sayesinde açık kama osteotomisinde oluşan komplikasyonların minimize edilmesidir. ${ }^{[1]}$

Buluşun bir başka amacı, yeni bir kılavuz yapılanması sayesinde Kirschner telleriyle osteotomi hattının belirlenmesinde skopi kullanım ihtiyacının azaltılmasıdır. ${ }^{[1]}$

Buluşun bir başka amacı da, osteotomi hattı belirlendikten sonra devreye alınan özel bir osteotom sayesinde son kesme işleminde derinlik kontrolünün sağlanmasıdır. ${ }^{[1]}$

Buluşun bir başka amacı ise, yeni bir açılı distraktör sayesinde osteotominin tamamlanması akabinde distraksiyonun tek alet ile gerçekleştirilebilmesinin sağlanmasıdır. ${ }^{[1]}$

Buluşun bir başka amacı distraksiyon açııı ve mesafesini gösterir açılı distraktör ile distraksiyon işleminde kontrolün kolaylaştırılmasıdır. ${ }^{[1]}$ 
Buluşun bir amacı da distraktörün ön ve arkasına konan yeni takoz elemanları sayesinde açılı distraktör çıkarıldığında elde edilen düzeltme mesafesinin kapanmasının engellenmesidir. ${ }^{[1]}$

Bahsedilen amaçlara ulaşmak üzere, açık kama osteotomisinde tibia proksimaline uzanan Kirschner telleri ile osteotomi hattının belirlenmesi için Kirschner tel yuvasına sahip bir kılavuz cihazı geliştirilmiştir. ${ }^{[1]}$

Buluşun tercih edilen bir uygulamasında, bahsedilen kılavuz cihazı; bahsedilen Kirschner tel yuvasını cildin üzerinde fibula başı üzerinde sabitleyecek şekilde tel yuvasını taşıyan bir sıkışırma uzantısına sahip en az bir mengene vasıtası içermektedir. ${ }^{[1]}$

Buluşun tercih edilen bir uygulamasında, bahsedilen mengene vasıtası, mengene açılma kabiliyetini tayin eden ve mengene hazne tabanını formlayan en az bir taşıyıcı gövde, bir yandan bahsedilen taşıyıcı gövde ucuna irtibatlı, diğer yandan tercihen Kirschner tel yuvasını barındıran, en az bir mengene çene uzantısı, bahsedilen taşıyıcı gövde üzerinde hareketli olarak mafsallanan (eklemleşen) en az bir mengene destek çenesi, bahsedilen mengene destek çenesinin bahsedilen taşıyıcı gövde üzerinde istenen konumda sabitlenmesini sağlamak üzere taşıyıcı gövde ve destek çenesi arasında oluşturulan en az bir sabitleme elemanı ile gerçekleştirilmiştir. Kirschner tel yuvası çene uzantılarından herhangi biri üzerinde konumlandirılabilmektedir. ${ }^{[1]}$

Buluşun tercih edilen bir uygulamasında, bahsedilen mengene destek çenesinin temas ettiği cilde zarar vermesini engellemek üzere uç kısmında en az bir set oluşturulmuştur. ${ }^{\left[{ }^{[1]}\right.}$

Buluşun tercih edilen bir uygulamasında, çok sayıda Kirschner telinin uygulanmasını sağlamak üzere bahsedilen kılavuz ciha$\mathrm{zI}$, bahsedilen mengene çene uzantısı üzerinde konumlandırılan en az bir yatak elemani, bahsedilen yatak elemanına oturan karşılık uzantısına sahip ve çoklu sayıda Kirschner teli deliği içeren en az bir tel yatak elemanı içermektedir. ${ }^{[1]}$

Bahsedilen amaçlara ulaşmak üzere açık kama osteotomisinde, osteotomi hattı belirlendikten sonra korteksin kesilmesi esnasında lateral korteksin kesilmesini engellemek üzere yeni bir osteotom geliştirilmiştir. ${ }^{[1]}$

Buluşun tercih edilen bir uygulamasında bahsedilen osteotom; uçtan sap kısmına doğru kalınlaşan " $U$ " formlu karşı ucu açık osteotom uzantısı, bahsedilen osteotom uzantısının kullanıc tarafindan tutulması için bir yandan bahsedilen osteotom uzantısı ile irtibatlanan en az bir sap elemanı içermektedir. ${ }^{[1]}$

Buluşun tercih edilen bir uygulamasında, bahsedilen osteotom uzantısı üzerinde mesafe tayinini sağlamak üzere mesafe skalası (gösterge çizelgesi) vasıtası irtibatlanmıştır. ${ }^{[1]}$

Bahsedilen amaçlara ulaşmak üzere açık kama osteotomisinde, osteotomi işlemi sonrasında distraksiyon gerçekleştirmek üzere yeni bir distraktör oluşturulmuştur. ${ }^{[1]}$
Buluşun tercih edilen bir uygulamasında, bahsedilen distraktör osteotomi alanına doğru uzanan en az bir alt gövde, bir yandan bahsedilen alt gövdenin osteotomi alanına giren ucundan alt gövde ile mafsallanan, diğer yandan osteotomi alanına giriş doğrultusuyla esasen açı oluşturacak şekilde yükseltilebilen en az bir üst gövde, bahsedilen gövdelerden bir değişken açılı kama teşkili için bahsedilen gövdelerin mafsallı olmayan uçları arasındaki mesafeyi değiştiren en az bir asansör elemanı içermektedir. Bu sayede kama distrakte edilecek bölgeye alt ve üst gövde kapalı halde iken yaklaşık $2^{\circ}$ açı oluşturacak şekilde sokularak içerisinde asansör elemanının açıyı değiştirmesi ile istenen seviyeye kemik alıştırarak çıkarılabilmektedir. ${ }^{[1]}$

Buluşun tercih edilen bir uygulamasında, bahsedilen osteotomi alanı giriş mesafesini ölçmek üzere gövdelerden herhangi biri üzerinde en az bir mesafe skalası oluşturulmuştur. ${ }^{[1]}$

Buluşun tercih edilen bir uygulamasında, kemiğin içine ilk girişin kolaylaştırılması için bahsedilen gövdelerden herhangi biri uç kısmında kama yüzeyi oluşturulmuştur. ${ }^{[1]}$

Buluşun tercih edilen bir uygulamasında bahsedilen asansör elemanı; bahsedilen gövdelerden biri üzerinde açılan en az bir vida yuvası, bahsedilen vida yuvası içerisinden geçen ve diğer kama üzerinde döner mafsallanarak sabitlenen en az bir vida elemanı ile gerçekleştirilmiştir. ${ }^{[1]}$

Buluşun tercih edilen bir uygulamasında, bahsedilen gövdelerin aralarının açılmasıyla oluşturdukları açının ölçülebilmesi için gövdeler arasında en az bir açı ölçme vasıtası oluşturulmuştur. ${ }^{[1]}$

Buluşun tercih edilen bir uygulamasında bahsedilen açı ölçme vasıtası, bahsedilen gövdelerden birinin açı oluşturma hareketi doğrultusunda uzanan diğer gövdeye ait en az bir ölçüm uzantısı, bahsedilen ölçüm uzantısı üzerinde oluşturulan en az bir açı skalası ve açı skalasına sahip olmayan gövde ucunda açı skalasına uzanacak şekilde oluşturulan en az bir gösterge elemanı ile gerçekleştirilmiştir. ${ }^{[1]}$

Buluşun tercih edilen bir uygulamasında, bahsedilen açı skalasını oluşturmak üzere bahsedilen ölçüm uzantısı üzerinde açılan ve bahsedilen gösterge elemanının girdiği en az bir boşluk oluşturulmuştur. [1]

Bahsedilen amaçlara ulaşmak üzere açık kama osteotomisinde, distraksiyon işlemi sonrasında plaka (plak) uygulamasını gerçekleştirmek amacıyla kama uygulama cihazı geliştirilmiştir. ${ }^{[1]}$

Buluşun tercih edilen bir uygulamasında bahsedilen kama uygulama cihazi; cerrah tarafindan kolay kullanım gerçekleştirmek üzere en az bir sap uzantısı, bahsedilen sap uzantısı ucunda oluşturulan en az bir kilitleme vasıtası ve bir yandan bahsedilen kilitleme vasıtası ile bahsedilen sap uzantısına kamanın sabitlenmesini sağlayan kama kilitleme yüzeyi içermektedir. ${ }^{[1]}$

Buluşun tercih edilen bir uygulamasında, bahsedilen kamanın uygulama sonrası gerilmelerle distraksiyon bölgesinden 
kaymasını engellemek üzere temas yüzeyinde oluşturulan en az bir pürüz elemanı içermektedir. ${ }^{[1]}$

Buluşun tercih edilen bir uygulamasında, bahsedilen kilitleme vasıtası bahsedilen sap ile irtibatlı ve bahsedilen kilitleme yüzeyinin oturduğu en az bir yuva ve bahsedilen yuva üzerinde hareketli şekilde irtibatlanan en az bir bilezik elemanı içermektedir. ${ }^{[1]}$ ”

\section{Buluşun Detaylı Açıklanması ${ }^{[1]}$}

Şekillerdeki (parçaların) referans numaraları[1]: (1) Kılavuz; (1.1) Taşıyıcı gövde, (1.2) Çene uzantısı, (1.3) Destek çenesi, (1.4) Sabitleme vidası, (1.5) Set, (1.6) Kirschner teli kılavuz yuvası, (1.7) Kirschner teli kılavuz sabitleyici, (1.8) Kirschner teli kılavuzu. (2) Osteotom; (2.1) Kama, (2.2) Sap, (2.3) Tutacak. (3) Distraktör; (3.1) Alt gövde, (3.2) Üst gövde, (3.3) Ölçüm uzantısı, (3.4) Açı skala boşluğu, (3.5) Vida yuvası, (3.6) Tahrik vidası, (3.7) Kapak, (3.8) Üst gövde vida hareket yuvası, (3.9) Kama ucu, (3.10) Alt gövde mafsal yuvası, (3.11) Üst gövde mafsal çıkıntısı, (3.12) Gösterge çııntısı. (4) Destek takozu uygulama cihazı; (4.1) Sap, (4.2) Takoz yuvası, (4.3) Vidalı bilezik, (4.4) Takoz/Kama, (4.5) Montaj çıkıntısı.

"Buluşun şekillerde verilen yardımcı el aletleri kullanılarak gerçekleştirilen temsili uygulamalarında medialden açık kama osteotomisinde, medialden laterale doğru kemik değişik açılarda kesilmekte (osteotomize edilmekte) ve önceden hesaplanan varus deformitesi oranında osteotomize edilen kemik yüzeyleri düzeltilmek istenen açı kadar birbirinden uzaklaştırılarak değişik tespit materyalleriyle tespit edilmektedir. ${ }^{[1]}$

Medialden açık kama osteotomisi uygularken cilt kesisi sonrası derinleşilerek uygun yöntemle proksimal tibianın medial bölümü ortaya konulmaktadır. Teknik olarak medialden laterale doğru, hastanın boy uzunluğu ve tibiasının uzunluğuyla değişmek üzere medialde eklem hattının 3-4 cm distalinden ve lateralde eklem hattının $1 \mathrm{~cm}$ distali ile lateral korteksin $1 \mathrm{~cm}$ medialine doğru, tuberositas tibianın üzerinden geçecek şekilde osteotomi hattının belirlenmesi gerekir. Bu işlem bir kılavuz (1) yardımıyla Kirschner tellerinin gönderilmesiyle gerçekleştirilmektedir. ${ }^{[1,3,4,6]}$

Buluşun Şekil 1 ve 2'de görülen uygulamalarında Kirschner teli göndermek için kullanılan kılavuz görülmektedir. Söz konusu kılavuz (1) silindirik bir taşıyıcı gövdenin (1.1) "L" formuna getirilmesi ile bir ucunda elde edilen çene uzantısı (1.2) ve söz konusu taşıııcı gövde (1.1) silindirik uzantısı üzerine geçirilen bir destek çenesinden (1.3) müteşekkil mengene formundadır. ${ }^{[1]}$

Destek çenesinin (1.3) bir ucu taşıııcı gövde (1.1) üzerinde ilerleme hareketi gerçekleştirebilmek için içi boş silindirik yapıdadır. Söz konusu boş silindirik yapı içerisinden taşıııı gövde (1.1) teleskopik olarak geçmektedir. Taşıyıcı gövde (1.1) üst yüzünde ve buna mukabil destek çenesi (1.3) iç yüzünde silindirik geçmede dönmeyi engellemek üzere bir yüzey düzlemseldir. Destek çenesinin (1.3) içi boş silindirik ucunun devamı çene uzantısına doğru eğimli bir uzantı formundadır. Söz konusu uzantının son ucu ise sıkıştırma halinde uygulanan kişiye temas edecek olduğundan dairesel yüzeyi çene uzantısına (1.2) bakan küçük bir silindir formunda bir sete (1.5) sahiptir. Set (1.5), mengene yapısındaki kılavuzun hareketli kolu işlevini gerçekleştiren destek çenesinin (1.3) eğimli kolunun uç kısmında $45^{\circ}$ açılla konumlandırılmıştır. ${ }^{[1]}$

Taşıyıcı gövde (1.1) üzerindeki çene uzantısı ise bahsedilen set (1.5) ile aynı hizada bir iç boşluğu barındıran silindirik Kirschner teli kılavuz yuvası (1.6) içermektedir. Yuva (1.6) içerisine dikdörtgen prizmatik bir gövdenin bir ucunda bahsedilen yuvaya uygun silindirik uzantı içerir formda yapılandırılan Kirschner teli kılavuzu (1.8) oturtulmaktadır. Kirschner teli kılavuzu (1.8) içerisinden biri yuva (1.6) merkezine açılmak üzere beş delik bulunmaktadır. ${ }^{[1]}$

Bahsedilen Kirschner teli kılavuzunun (1.8) yuva (1.6) içerisinde sabitlenmesini sağlamak üzere yuva (1.6) üzerinde açılmış bir vida deliğine cıvata formlu Kirschner teli kılavuzu sabitleyici (1.7) takılmaktadır. Söz konusu sabitleyici (1.7) çevrilerek yuva (1.6) içerisindeki kılavuzu (1.8) sıkıştırarak hareketini engellemektedir. ${ }^{[1]}$

Benzer bir sabitleme vasıtası taşıyıcı gövde (1.1) ile destek çenesi (1.3) arasında oluşturulmuştur. Destek çenesinin (1.3) içi boş silindirik ucunda açılan bir vidalı delik içerisinden geçen bir cıvata formunda sabitleme elemanı (1.4) döndürülerek destek çenesi (1.3) iç boşluğundaki taşıyıcı gövdeyi (1.1) sıkıştırmaktadır. ${ }^{[1]}$

Osteotomi hattının belirlenmesinde yukarıda bahsedilen elemanların oluşturduğu kılavuzdan (1) yardım alınmaktadır. Osteotomi bölgesi üzerinde taşıyıcı gövde (1.1) üzerinde destek çenesi (1.3) kaydırılarak kılavuz (1) sabitlenmektedir. Bu esnada cerrahtan uzakta olan hedef noktaya uygulama set (1.5) ile gerçekleştirilmiştir. Set (1.5) fibula başı seviyesine ancak ön tarafina yerleştirilmektedir. Cerraha yakın olan çene uzantısı (1.2) ise tibia proksimaline telin gönderilmek istendiği yere yerleştirilmektedir. Ardından Kirschner teli kılavuzu (1.8) yuvaya (1.6) oturtularak sabitlenmektedir. ilk tel yuva (1.6) ortasındaki delikten gönderilmekte ve kendiliğinden karşıdaki yuvayı bulmaktadır. Ĕger seviye uygunsa en az süreli skopi kullanarak osteotomi hattı bulunmuş olunmaktadır. Dikdörtgen prizmatik Kirschner teli kılavuz parçası (1.8) tibianın arkaya eğimi olan posterior slopa (eğime) göre ayarlanarak iki veya üç tel daha ilk tele paralel olarak gönderilmektedir. Böylece osteotomi hattı belirlenmiş olur. ${ }^{[1]}$

Kirschner tellerinin geçirilmesi sonrasında tellerin alt tarafindan (ayak tarafindan) osteotom veya kesici motorlar yardımıyla medial (iç), anterior (ön) ve posterior (arka) korteks kesilmektedir. Bu yöntemin etkili olabilmesi için lateral korteksin kesilmemesi ve bu bölümün plastiki 
deformasyon özelliğiyle menteşe özelliğinden faydalanılması gerekmektedir. ${ }^{[1]}$

Lateral korteksin kesilmesini engellemek üzere son kesme işlemi Şekil 3. a ve b'de görülen osteotom (3) ile gerçekleştirilmektedir. Söz konusu osteotom (3) bir yandan prizmatik bir gövde diğer yandan söz konusu gövdenin ortasında oluşturulmuş bir uzantıdan müteşekkil "T" formlu bir sap (2.2) üzerine kurulmuştur. Sapın (2.2) ucunda birer kama (2.1) "U" yapısı oluşturacak şekilde sabitlenmiştir. Sapın (2.2) uzantı kısmı ucuna ise cerrahın el ile tutabilmesi için bir tutacak (2.3) sabitlenmiştir. Kamaların (2.1) bir yüzeyi üzerinde santimetre cinsinden ölçüleri bulunan bir skala derinlik ölçme amacıyla sabitlenmiştir. Böylece ne kadar derinliğe ulaşıldığı görülerek kontrolsüz ve gereksiz derinlikte osteotomi uygulanması önlenmektedir. ${ }^{[1]}$

Kamalar (2.1) sap (2.2) kısma doğru kalınlaşmaktadır. Böylece uygulama esnasında hem osteotomi yüzeyleri arasında ilk distraksiyon hem de kemikte arzu edilen esneme sağlanmaktadır. ${ }^{[1]}$

Osteotomi sonrasında distraksiyon sağlamak üzere Şekil 4 ve Şekil 5'te temsili uygulaması gösterilen açı ölçerli üç temel parçalı bir distraktör (3) geliştirilmiştir. ${ }^{[1,8]}$ Distraktör (3) temel olarak bir alt gövde (3.1), bir ucundan alt gövde (3.1) ile mafsallı bir üst gövde (3.2) ve gövdeler (3.1 ve 3.2) arasında oluşturulan bir asansör tertibatından müteşekkildir. ${ }^{[1]}$

Alt gövde (3.1) ince kesitli ve bir kısa bir de uzun olmak üzere iki uzantıya sahip " $L$ " benzeri bir formdadır. Alt gövdenin (3.1) uzun kenar ucu bir kama (3.9) formunda üçgen kesitte yapılmıştır. Ayrıca kama ucun (3.9) arka kısmında kolun enlemesine uzantısı boyunca bir kanal açılarak alt gövde mafsal yuvası (3.10) oluşturulmuştur. Alt gövdede (3.1) kolların kesiştiği köşe kısmı dış etkenlerle oluşabilecek gerilmelerden dolayı kalın kesitlidir. Uzun kolun köşe kısmına yakın bölgesinde silindirik delik açılarak vida yuvası (3.5) oluşturulmuştur. ${ }^{[1]}$

Alt gövdenin (3.1) ölçüm uzantısı (3.3) oluşturan kısa kolu ise geniş yüzeyi üzerinde ise açı ölçer vazifesi görmek üzere düşey olarak bir açı skala (gösterge çizelgesi) boşluğuna (3.4) sahiptir. Skala boşluğunun (3.4) kenarlarına ise açı değerleri içeren rakamlar konumlandırılmıştır. Ölçüm uzantısının (3.3) serbest ucu uzun kola paralel olacak şekilde kıvrılmıştır. Oluşan yüzey üzerinde de bir silindirik vida yuvası (3.5) açılmıştır. ${ }^{[1]}$

Üst ve alt vida yuvaları (3.5) arasında tahrik (hareket ettirme) vidası (3.6) yataklanmıştır (yuvaya yerleştirilmiştir). Vida yuvalarına (3.5) diş açılmadığından ve tahrik vidasının (3.6) alt ucu düşük kenar sürtünmesi oluşturacak şekilde bir sonsuz vida teşkil etmektedir. Tahrik vidasının (3.6) alt ucu alt gövde (3.1) uzun kenarı üzerinden gelebilecek bir engelin temasını önlemek üzere bir kapak (3.7) aracılığılla kapatılmıştır. ${ }^{[1]}$
Üst gövde (3.2) bir ucuna doğru kalınlaşan ince ve üçgen benzeri kesitli bir yapıdadır. Üst gövdenin (3.2) alt uси bahsedilen alt gövde mafsal yuvasına (3.10) oturacak şekilde silindirik formludur. Üst ucunda ise kalın kesit formu içerisinde kesit boyunca oval bir yuva açılmıştır. Söz konusu yuva içerisine silindirik ve uzantı kısmı eğimli yanal yüzeyi ortasında dairesel kesitli ve vida açılmış delik bulunan iki ucu geniş çaplı bir makara benzeri formda üst gövde vida hareket yuvası aparatı (3.8) oturmaktadır. Bahsedilen üst gövde (3.2) üst yüzeyi içerisinden üst gövde vida hareket yuvasına (3.8) açılacak şekilde nispeten dar bir oval delik açılmıştır. ${ }^{[1]}$

Tahrik vidasının (3.6) üst gövde irtibatı vida hareket yuvası aparatı (3.8) yardımıyla gerçekleşmektedir. Tahrik vidası (3.6) üzerindeki yiv, hareket yuvası (3.8) içerisindeki karşı yiv ile temas ederek yuva aparatının (3.8) üst gövdeyi (3.2) bir ucundan alt gövdenin (3.1) paralel ucuna göre mesafeli taşımasını sağlamaktadır. Tahrik vidasının (3.6) çevrilmesi ile bir ucundan alt gövdeye mafsallanan (3.10) üst gövdenin (3.2) serbest ucundan düş̧ey doğrultuda kaldırılması veya indirilmesi sağlanmaktadır. ${ }^{[1]}$

Üst gövdenin (3.2) serbest uç kısmında alt gövde (3.1) açı skala boşluğuna (3.4) giren bir uzantı formunda gösterge çıkıntısı (3.12) bulunmaktadır. Üst gövdenin (3.2) tahrik vidası (3.6) marifetiyle serbest uç düşey konumunun değişmesi esnasında gösterge çıkıntısı (3.12) serbest uç konumunu yani alt gövde (3.1) ile üst gövde (3.2) aralarındaki açıyı göstermektedir. Üst gövde (3.2) ve alt gövde (3.1) dış yüzeyleri üzerinde giriş derinliğini gösteren santimetre cinsinden skalalar da bulunmaktadır. ${ }^{[1]}$

Osteotomi alanına skopi eşliğinde alt ve üst gövdenin (3.1 ve 3.2) mafsallı uçları sokulmaktadır. Ince kenarlı kama uçlu (3.9) yapısı sayesinde distraktör itilerek veya gerektiğinde çakılarak uygulanabilir. Çakılması gerektiğinde uygulanan kuvvet nedeniyle gerilmelere binaen alt gövde (3.1) kalın kesitli gerçekleștirilebilir. Bir tornavida yardımıyla tahrik vidasının (3.6) yavaşça çevrilmesi sayesinde kemiğe dinlenme firsatı da verilerek üst ve alt gövdeye (3.1 ve 3.2) temas eden kemik kesi yüzeyleri birbirinden ayrılmaktadır. Açı skala boşluğu (3.4) içerisinden gösterge çıkıntısı (3.12) yardımıla distraksiyon açısı ölçülmektedir. ${ }^{[1]}$

Açı ölçerli distraktör (3) sayesinde distraksiyonun tamamlanması akabinde bölgeye plak uygulanabilmesi için distraktör (3) çıkarılmaktadır. Ancak, distraktör çıkartıldıktan sonra elde edilen düzelme oranı kaybolmasın ve distraksiyon mesafesi kapanmasın diye, açı ölçerli distraktörün önüne ve arkasına takoz vazifesi görecek desteklerin konması gerekmektedir. Bu amaçla üzerinde derinlik gösterir $\mathrm{cm}$ cinsinden uzunluk değerleri ile uygulanacak plak kama yükseklĭgine uyan kemik yüzeyleri arasındaki uzaklaşma miktarını $\mathrm{mm}$ cinsinden gösteren yükseklik değerlerinin olduğu kamalar (4.4) bu alana uygulanır. Buluşun Şekil 6 ve 7'de görülen 
uygulamalarında, destek takozu uygulama tertibatını oluşturan parçaların birleştirilmiş (montaj) ve ayrıştırılmış (demontaj) görünümleri verilmiştir. ${ }^{[1]}$

Kamaların/takozların (4.4) uzunluğu buluşun mevcut uygulamasında 60-65 $\mathrm{mm}$ olup yarım $\mathrm{cm}$ arayla kemiğin içerisine giren yan yüzde kısım skala ile belirtilmiştir; plak kama yüksekliklerine uyacak 5-15 mm arası değerler de üst ve alt yüzlerde skala ile belirtilmiştir. Kamalar (4.4) kolay uygulanabilmek için, çıkartılacak/ayrılacak şekilde bir kilit mekanizmasıyla sap bölgesine (4.1) tespit edilmektedir. ${ }^{[1]}$

Kilit mekanizmasını gerçekleştirmek üzere silindirik sap (4.1) uси bir yuva (4.2) içeren kademeli yüzey şeklinde formlanmıştır. Kademe üzerinde vida yuvası açılmıştır. Söz konusu vida yuvası üzerine ise bir vidalı bilezik (4.3) takılmıştır. Takozun (4.4) arka ucunda oluşturulan ve bahsedilen yuva (4.2) ile uyumlu olan " $L$ " formundaki montaj çıkıntısının (4.5) yuvaya oturtulması akabinde bilezik (4.3) çevrilerek yuva (4.2) üzerini kapatmakta ve yuva (4.2) içerisinde kama/takoz (4.4) uzantısını hapsetmesi sağlanmaktadır. ${ }^{[1]}$

Kamalar (4.4) özellikle alt kesi yüzeyini vücut orta hattından dışarıya doğru uzaklaştıracak (valgus efekti verecek) şekilde, tabanı sapa (4.1) komşu kısımda olup üst kesi yüzeyine uyan bölümüyle $90^{\circ}$ (dik) açı yapacak şekilde planlanmıştır. Kamanın (4.4) kemikle temas eden bölümlerine, uygulama sonrası geriye doğru kaymaması için örneğin porozlamayla enlemesine oluklar açılmıştır (Şekilde gösterilmemiştir). ${ }^{[1]}$

Tibianın plak uygulanacak bu medial kısmı (iç tarafi) kişiden kişiye farklı genişliklerde olabileceği için, takoz vazifesini görecek bu kamalar (4.4) farklı genişliklerde ve derinliklerde yapılabilmektedir. Kemik yüzeylerine temas eden ve geriye doğru kaymasını engelleyen yüzeye çeşitli şekillerde pürüz verilebilmektedir; enlemesine, çapraz, baklava şeklinde veya boncuklar şeklinde olabilir. ${ }^{[1]}$

Kama (4.4) tabanı sapa (4.1) tespit edilen bölümde dik üçgen şeklinde olabileceği gibi, yine sapla (4.1) temas eden taban kısmından itibaren kemikyüzeylerini destekleyen kısmı ikizkenar üçgen şeklinde olabilir. Uygulama kolaylığı açısından, takozların (4.4) her biri geçmeli veya kaydırmalı bir kilit mekanizmasıyla sap kısmına tutturulmakta ve uygulama bitince bu sap kısmı (4.1) çıkartılmaktadır. Açı ölçerli distraktör (3) çıkartıldıktan sonra, iki takoz arasına istenilen plak uygulanir ve tespit edilir. ${ }^{[1]}$

Buluş bu bölümde verilen temsili uygulamalar ile sınırlı tutulamaz. Istemlerde belirtilen koruma kapsamındaki temel unsurlar esas olmak üzere teknik alanda uzman kişilerce gerçekleştirilebilecek alternatif yapılanmalar buluşun ihlali anlamını taşıyacaktır. ${ }^{[1]}$ "

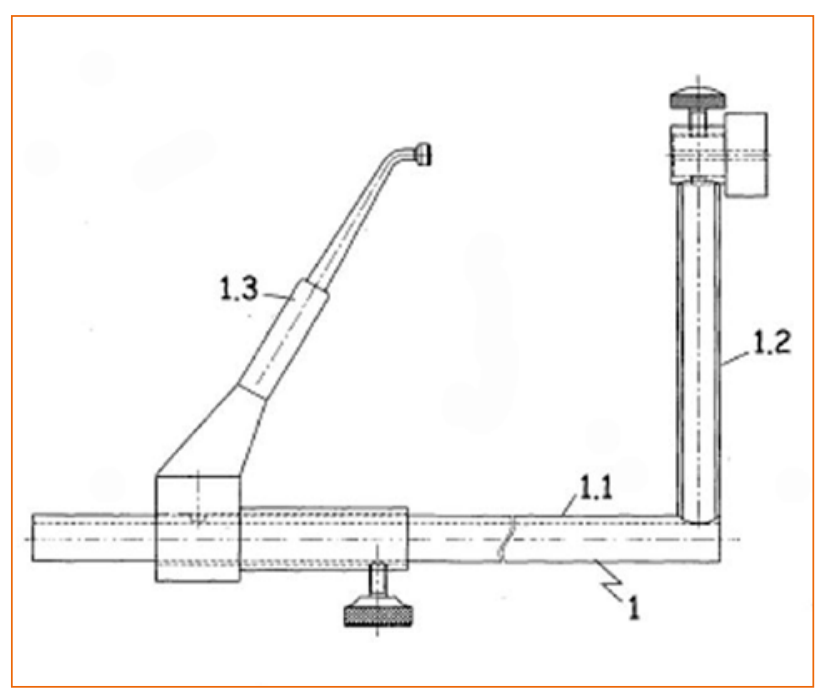

Şekil 1. Açık kama osteotomisinde kullanılan buluş konusu kılavuz cihazının temsili bir uygulamasının montaj (parçaların birleştirilmiş) görünümüdür.[1]

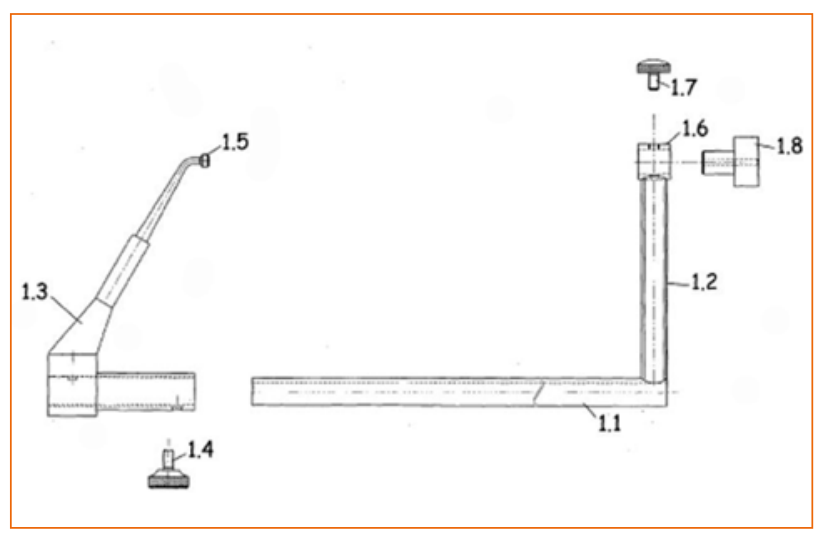

Şekil 2. Şekil 1'de gösterilen kılavuz cihazının temsili bir uygulamasının demontaj (parçaların sökülmüş) görünümüdür. ${ }^{[1]}$

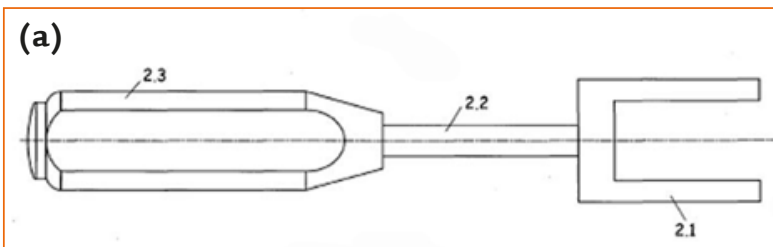

(b)

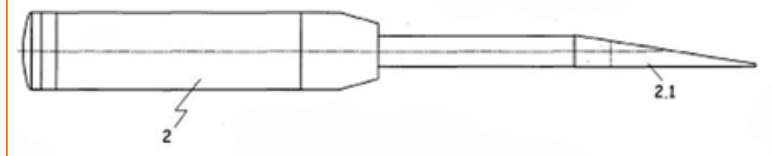

Şekil 3. a, b. Açık kama osteotomisinde kullanılan buluş konusu osteotomun temsili bir uygulamasının üstten görünümüdür (a). Şekil 3a'da verilen osteotomun temsili bir uygulamasının yandan görünümüdür (b). ${ }^{[1]}$ 


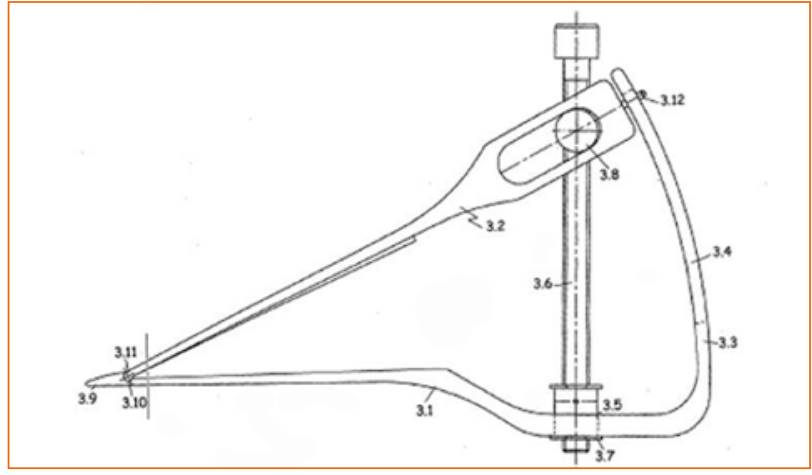

Şekil 4. Açık kama osteotomisinde kullanılan buluş konusu distraktörün temsili bir uygulamasının montaj görünümüdür. ${ }^{[1]}$

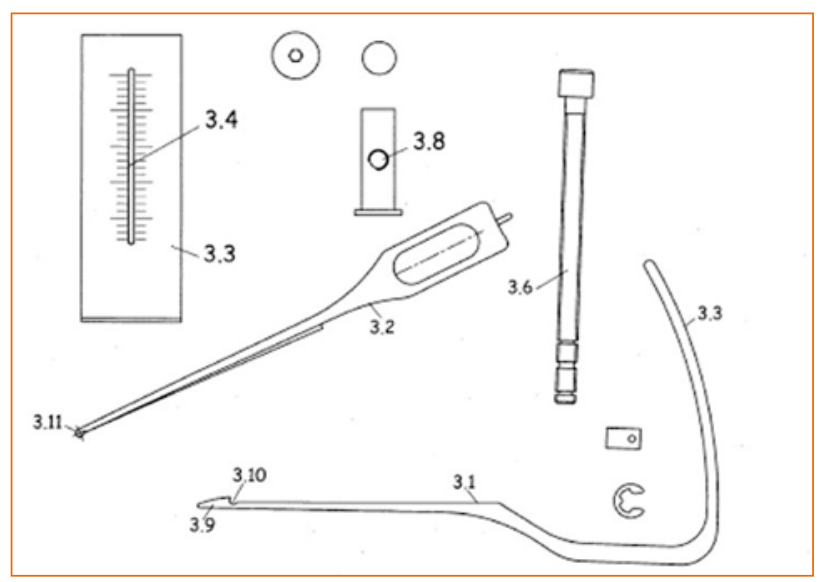

Şekil 5. Şekil 4'te gösterilen distraktörün temsili bir uygulamasının demontaj görünümüdür. ${ }^{[1]}$

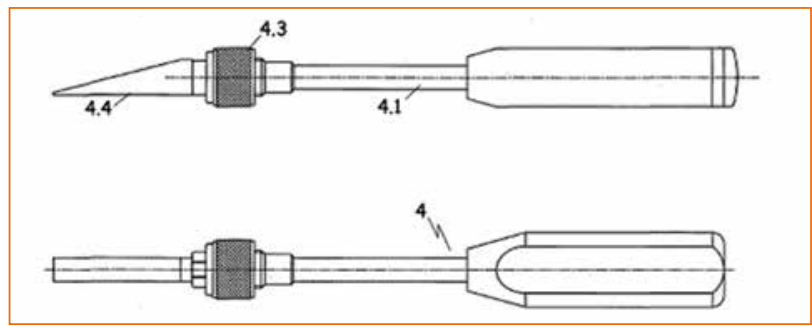

Şekil 6. Açık kama osteotomisinde kullanılan buluş konusu destek takozu uygulama tertibatının montaj görünümüdür. ${ }^{[1]}$

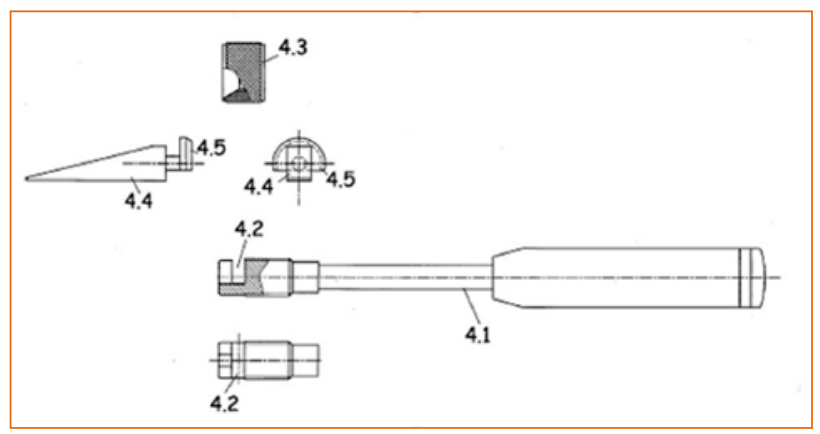

Şekil 7. Şekil 6'da verilen destek takozu uygulama tertibatının demontaj görünümüdür. ${ }^{[1]}$

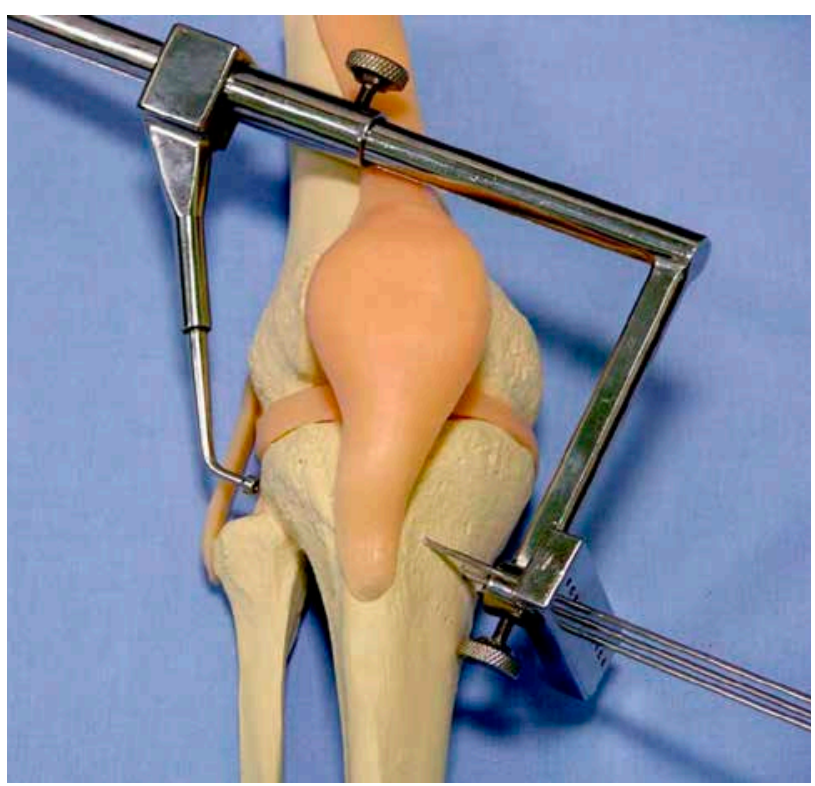

Şekil 8. Şekil 1 ve 2'de teknik resim çizimleri verilen ve osteotomi hattını belirlemek için kullanılan Kirschner teli kılavuzunun plastik kemik model üzerinde uygulanmış görünümüdür.
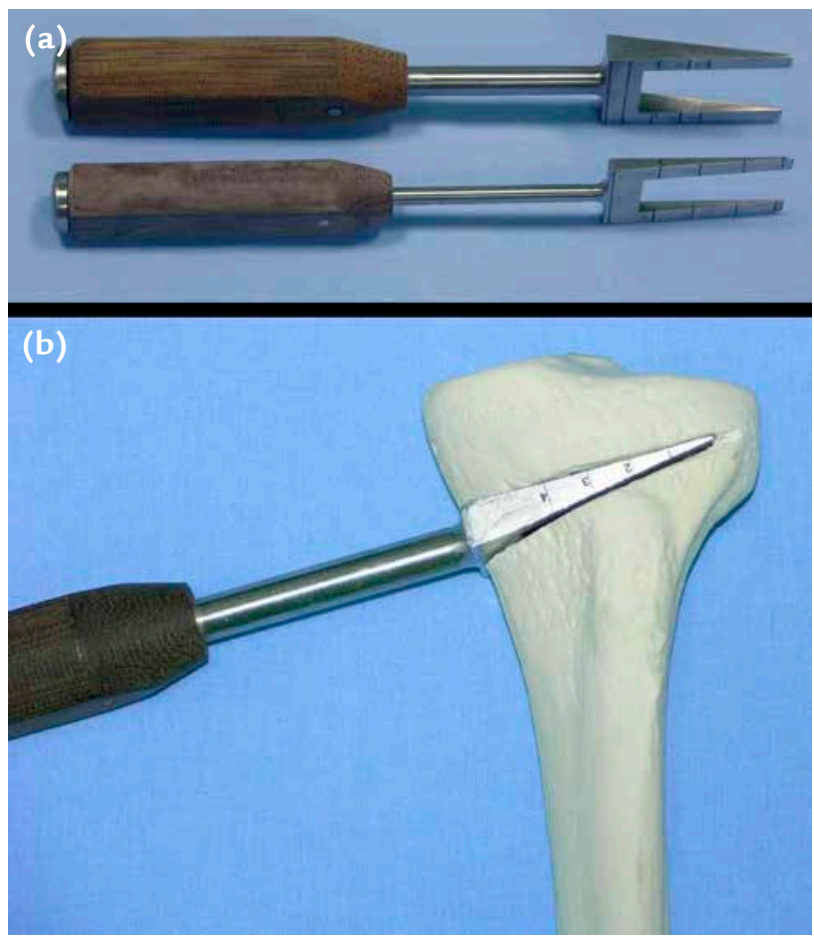

Şekil 9. a, b. Şekil 3a ve 3b'de teknik resim çizimleri verilen ve lateral korteksi kesmeden osteotomi hattının kesilerek distrakte olmasını sağlayan farklı kalınlıktaki "U” şeklindeki osteotomların serbest (a) ve kemik model üzerinde uygulanmış (b) görünümleridir. 


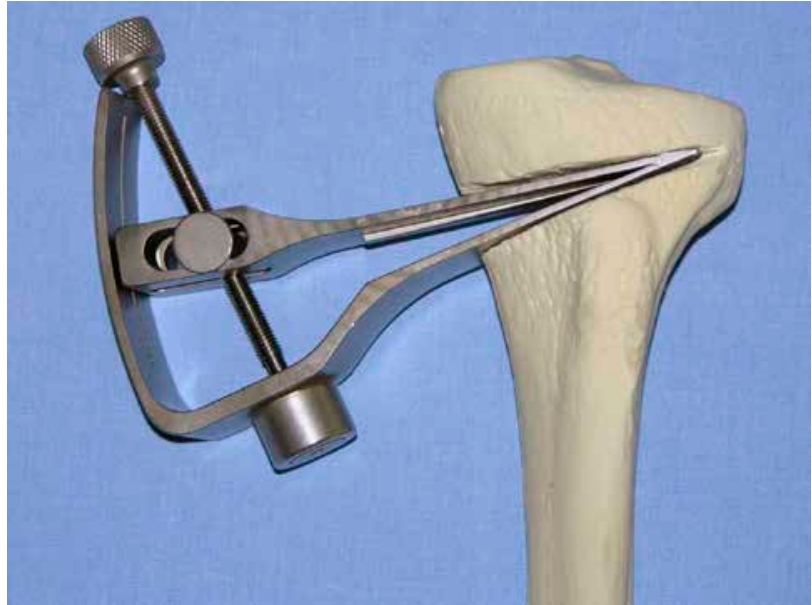

Şekil 10. Şekil 4 ve 5'te teknik resim çizimleri verilen açı göstergeli distraktörün plastik kemik model üzerinde uygulanmış görünümüdür.

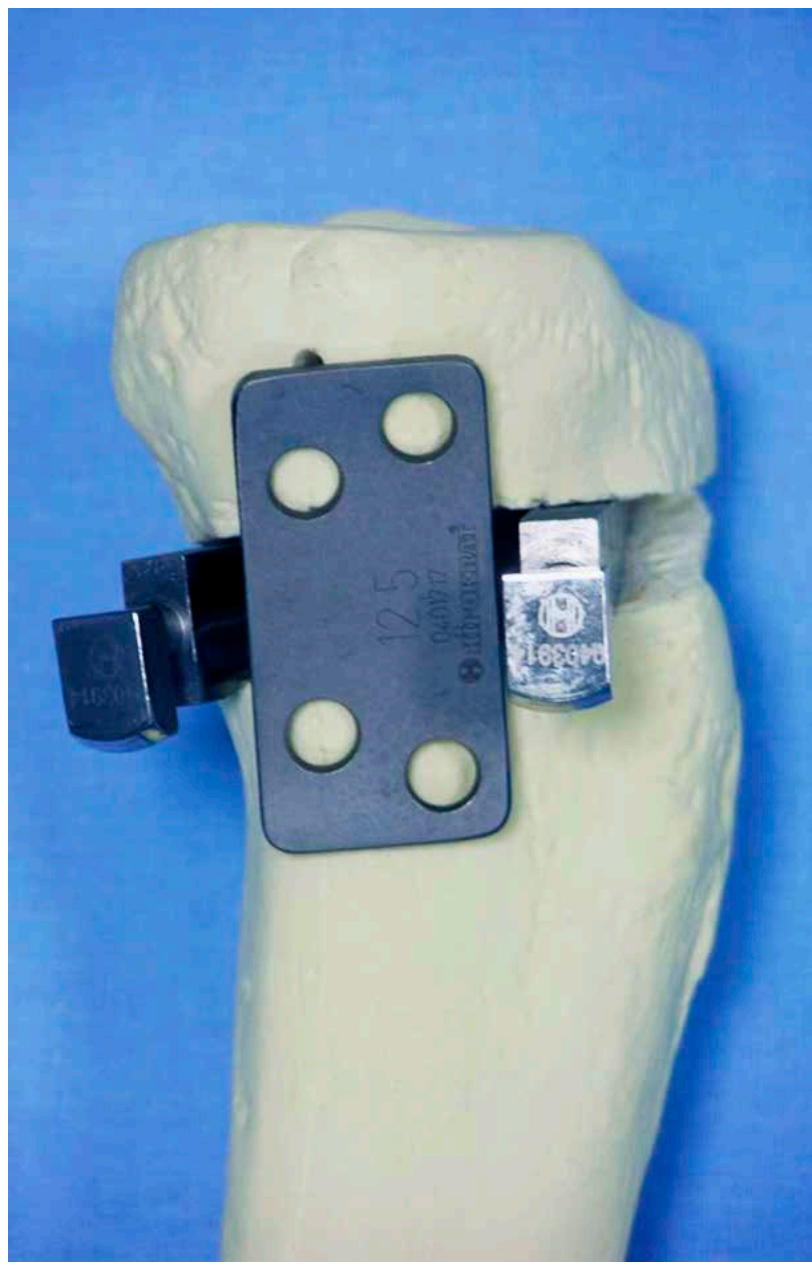

Şekil 11. Şekil 6 ve 7'de teknik resim çizimleri verilen, osteotomi hattını açmak ve açılan yüksekliği korumak için kullanılan takoz vazifesi gören kamaların plastik kemik model üzerinde uygulanmış görünümüdür.
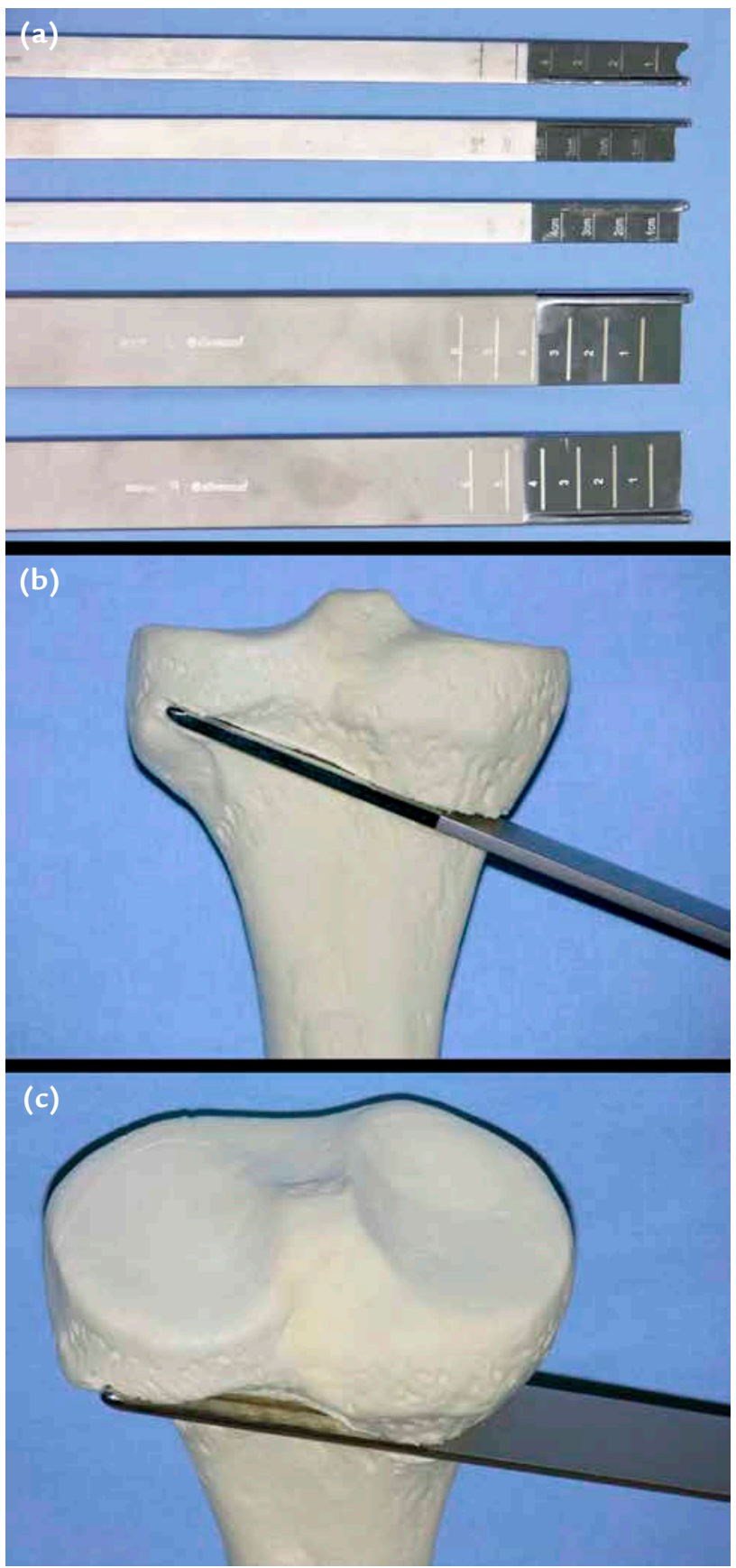

Şekil 12. a-c. Aynı ameliyatta kullanılan, proksimal tibia posteriorunda yerleşen damar-sinir yapılarına zarar vermemek için arka tarafa bakan köşe-kenar bölümü künt olarak tasarlanmış olan osteotomların serbest (a), plastik kemik model üzerinde arka taraftan (b) ve yukarıdan (c) görünümleri. 


\section{İstemler ${ }^{[1]}$}

1. Buluş, açık kama osteotomisinde tibia proksimaline uzanan Kirschner telleri ile osteotomi hattının belirlenmesi için Kirschner teli yuvasına sahip kılavuz cihazı (1) olup özelliği,

- bahsedilen Kirschner teli yuvasını cildin üzerinde fibula başı üzerinde sabitleyecek şekilde taşıyan bir sıkıştırma uzantısına (1.3) sahip en az bir mengene vasıtası (1.1 ve 1.2) içermesidir. ${ }^{[1]}$

2. İstem 1'e uygun bir kılavuz elemanı ile ilgili olup özelliği, Kirschner teli yuvasını (1.8) barındıran bahsedilen mengene vasıtasını gerçekleştirmek üzere,

- mengene açılma kabiliyetini tayin eden ve mengene hazne tabanını formlayan en az bir taşıyıcı gövde (1.1),

- bir yandan bahsedilen taşıyıcı gövde (1.1) ucuna irtibatı en az bir mengene çene uzantısı (1.2),

- bahsedilen taşıyıcı gövde (1.1) üzerinde hareketli olarak mafsallanan en az bir mengene destek çenesi (1.3),

- bahsedilen mengene destek çenesinin (1.3) bahsedilen taşıyıcı gövde (1.1) üzerinde istenen konumda sabitlenmesini sağlamak üzere taşıyıcı gövde (1.1) ve destek çenesi (1.3) arasında oluşturulan en az bir sabitleme elemanı (1.4) içermesidir. ${ }^{[1]}$

3. İstem 2'ye uygun bir kılavuz elemanı ile ilgili olup özelliği, bahsedilen mengene destek çenesinin (1.3) temas ettiği cilde zarar vermesini engellemek üzere uç kısmında oluşturulan en az bir set (1.5) ile karakterize edilmektedir. ${ }^{[1]}$

4. Yukarıdaki istemlerden herhangi birine uygun bir kılavuz elemanı ile ilgili olup özelliği, çok sayıda Kirschner telinin uygulanmasını sağlamak üzere,

- bahsedilen çene uzantılarından biri (1.2 ve 1.3) üzerinde konumlandırılan en az bir yatak elemanı (1.6),

- bahsedilen yatak elemanına (1.6) oturan karşılık uzantısına sahip ve çoklu sayıda Kirschner teli deliği içeren en az bir tel yatak elemanı (1.8) içermesidir. ${ }^{[1]}$

5. Buluş, açık kama osteotomisinde, osteotomi hattı belirlendikten sonra korteksin kesilmesi esnasında lateral korteksin kesilmesini engellemek üzere oluşturulan osteotom (2) olup özelliği,

- uçtan sap kısmına doğru kalınlaşan "U” formlu karşı ucu açık osteotom uzantısı (2.1),

- bahsedilen osteotom uzantısının (2.1) kullanıcı tarafindan tutulması için bir yandan bahsedilen osteotom uzantısı (2.1) ile irtibatlanan en az bir sap elemanı (2.2 ve 2.3) içermesidir. ${ }^{[1]}$

6. İstem 5'e uygun bir osteotom olup özelliği, bahsedilen osteotom uzantısı (2.1) üzerinde mesafe tayinini sağlamak üzere irtibatlanan mesafe skalası vasıtası içermesidir. ${ }^{[1]}$
7. Buluş, açık kama osteotomisinde, osteotomi işlemi sonrasında distraksiyon gerçekleştirmek üzere oluşturulan distraktör (3) olup özelliği,

- osteotomi alanına doğru uzanan en az bir alt gövde (3.1),

- bir yandan bahsedilen alt gövdenin (3.1) osteotomi alanına giren ucundan alt gövde (3.1) ile mafsallanan diğer yandan osteotomi alanına giriş doğrultusuyla esasen açı oluşturacak şekilde yükseltilebilen en az bir üst gövde (3.2),

- bahsedilen gövdelerden (3.1 ve 3.2) bir değişken açılı kama teşkili için bahsedilen gövdelerin $(3.1$ ve 3,2$)$ mafsallı olmayan uçlan arasındaki mesafeyi değiştiren en az bir asansör elemanı (3.6) içermesidir. ${ }^{[1]}$

8. İstem 7'ye uygun bir distraktör (3) olup özelliği, bahsedilen osteotomi alanı giriş mesafesini ölçmek üzere gövdelerden (3.1 ve 3.2) herhangi biri üzerinde oluşturulan en az bir mesafe skalası içermesidir. ${ }^{[1]}$

9. İstem 7 veya istem 8'e uygun bir distraktör (3) olup özelliği, kemiğin içine ilk girişin kolaylaştırılması için bahsedilen gövdelerden (3.1 ve 3.2) herhangi biri uç kısmında oluşturulan kama yüzeyi (3.9) içermesidir. ${ }^{[1]}$

10. Istem 7, 8 veya 9'a uygun bir distraktör (3) olup özelli$\breve{g} i$, bahsedilen asansör elemanını gerçekleştirmek üzere,

- bahsedilen gövdelerden (3.1 ve 3.2) biri üzerinde açılan en az bir vida yuvası (3.8),

- bahsedilen vida yuvası (3.8) içerisinden geçen ve diğer gövde üzerinde döner mafsallanarak (3.5) sabitlenen en az bir vida elemanı (3.6) içermesidir. ${ }^{[1]}$

11. Istem 7, 8, 9 veya 10'a uygun bir distraktör (3) olup özelliği, bahsedilen gövdelerin (3.1 ve 3.2) aralarının açılmasıyla oluşturdukları açının ölçülebilmesi için gövdeler (3.1 ve 3.2) arasında oluşturulan en az bir açı ölçme vasıtası içermesidir. ${ }^{[1]}$

12. Istem 11'e uygun bir distraktör (3) olup özelliği, bahsedilen açı ölçme vasıtasını gerçekleştirmek üzere,

- bahsedilen gövdelerden (3.1 ve 3.2) birinin açı oluşturma hareketi doğrultusunda uzanan diğer gövdeye (3.2 ve 3.1) ait en az bir ölçüm uzantısı (3.3),

- bahsedilen ölçüm uzantısı (3.3) üzerinde oluşturulan en az bir açı skalası,

- açı skalasına sahip olmayan gövde (3.1 ve 3.2) ucunda açı skalasına uzanacak şekilde oluşturulan en az bir gösterge elemanı (3.12) içermesidir. ${ }^{[1]}$

13. İstem 12'ye uygun bir distraktör (3) olup özelliği, bahsedilen açı skalasını oluşturmak üzere bahsedilen ölçüm uzantısı (3.3) üzerinde açılan ve bahsedilen gösterge elemanının (3.12) girdiği en az bir boşluk (3.4) içermesidir. ${ }^{[1]}$ 
14. Buluş, açık kama osteotomisinde, distraksiyon işlemi sonrasında plaka (plak) uygulamasını gerçekleştirmek üzere kama uygulama cihazı (4) olup özelliği,

- cerrah tarafindan kolay kullanım gerçekleştirmek üzere en az bir sap uzantısı (4.1),

- bahsedilen sap uzantısı (4.1) ucunda oluşturulan en az bir kilitleme vasıtası,

- bir yandan bahsedilen kilitleme vasıtası ile bahsedilen sap uzantısına (4.1) kamanın (4.4) sabitlenmesini să̆layan kama kilitleme yüzeyi (4.5) içermesidir. ${ }^{[1]}$

15. İstem 14'e uygun bir kama uygulama cihazı olup özelliği, bahsedilen kamanın (4.4) uygulama sonrası gerilmelerle distraksiyon bölgesinden kaymasını engellemek üzere temas yüzeyinde oluşturulan en az bir pürüz elemanı içermesidir. ${ }^{[1]}$

16. İstem 14'e uygun bir kama uygulama cihazı olup özelliği, bahsedilen kilitleme vasıtasını gerçekleştirmek üzere,

- bahsedilen sap ile irtibatı ve bahsedilen kilitleme yüzeyinin oturduğu en az bir yuva (4.2) ve

- bahsedilen yuva üzerinde hareketli şekilde irtibatlanan en az bir bilezik elemanı (4.3) içermesidir. ${ }^{[1]}$

\section{YAZARIN KONUYLA ILGILI ÇALIŞMALARI}

Genu varum deformitesine medial tibiofemoral kompartman osteoartrozunun eşlik ettiği 65 yaş altı hasta grubunda proksimal tibia medial açık kama ostetomisi yaygın olarak kullanılmaktadır. Teknik mediaden tek planda (monoplanar) ${ }^{[3-6,8-13]}$ veya iki planlı (biplanar $)^{[7,14-18]}$ olarak uygulanabilir Yazar tespit için, tasarımını oluşturduğu iki veya dört delikli, dikdörtgen, konik ya da ters " $L$ " şeklindeki plaklardan birini veya ikisini kullanmaktadır. ${ }^{[2,3,8-18]}$

Osteotomi esnasında kullanılan ve faydalı model belgesi alınmasına konu olan el aletleri ameliyatın kolayca uygulanması, oluşabilecek bazı komplikasyonları önleme ve skopi kullanımını en aza indirmek amacı ile yazar tarafından tasarlanmıştır. Tasarımı yapılan el aletleri, özellikle tek planda (monoplanar) uygulanan osteotomiler için tasarlanmıştır. ${ }^{[3,8-13]}$ Biplanar retrotüberkül osteotomisinde tibial tüberkülün içinde bulunduğu gaga kısmı bu bölgedeki kemik genişliğinin 1/3'ü kadar olduğundan, açı göstergeli distraktörün genişliği de oblik osteotominin uygulandığı kalan kemik genişliği oranında modifiye edilmiştir. ${ }^{[8,14-18]}$ Şekil 8-11'de, Şekil 1-7'de teknik resim çizimleri verilen el aletlerinin serbest ya da plastik kemik modeller üzerindeki uygulama görünümleri verilmiştir: Şekil 8'de Kirschner teli kılavuzuna, Şekil 9'da “U” şeklindeki osteotomlara, Şekil 10'da açı göstergeli distraktöre ve Şekil 11'de açılan yüksekliği korumak için kullanılan ve takoz vazifesi gören kamalara ait serbest ve plastik kemik modeller üzerinde uygulama görüntüleri.

Ayrı bir faydalı model belgesi alındığı için yukarıda açıklamaları yapılan el (uygulama) aletlerine dâhil edilmeyen, ancak uygulama setinde mevcut olan, proksimal tibianın arkasındaki damar-sinir yapılarına zarar vermeyecek şekilde planlanan farklı genişliklerdeki özel osteotomlar da yine yazar tarafından tasarlanmıştır. Bahsedilen osteotomların kesici uçlarının arkaya bakan tarafları kesilen kemiğin önündeki sağlam kemikten destek alarak ilerleme sağlayacak şekilde künt bir çıkıntı içermektedir (Şekil 12). ${ }^{[19]}$

\section{KAYNAKLAR}

1. Medialden açık kama yüksek tibial osteotomisi tertibatı. T.C. Türk Patent Enstitüsü. Faydalı Model Belgesi. No: TR 200401749 Y. https://portal.turkpatent.gov.tr/anonim/ arastirma/patent/detayli

2. Diz eklemi çevresi kaynaklı deformitelerde kullanılmak üzere bir plak yapılanması. T.C. Türk Patent Enstitüsü. Faydalı Model Belgesi. No: TR 200202021 Y. https://portal. turkpatent.gov.tr/anonim/arastirma/patent/detayli

3. Esenkaya I. Fixation of proximal tibia medial opening wedge osteotomy using plates with wedge [Proksimal tibia medial açık kama osteotomisinde kamalı plak uygulaması]. Acta Orthop Trauma Turc 2005;39:211-23. https://www.aott. org.tr/en/fixation-of-proximal-tibia-medial-opening-wedgeosteotomy-using-plates-with-wedges-164753

4. Hernigou P, Medevielle D, Debeyre J, Goutallier D. Proximal tibial osteotomy for osteoarthritis with varus deformity: A ten to thirteen-year follow-up study. J Bone Joint Surg Am 1987;69:332-54. Crossref

5. Spahn G. Complications in high tibial (medial opening wedge) osteotomy. Arch Orthop Trauma Surg 2004;124:649-53. Crossref

6. Arthrex. Opening Wedge Osteotomy. Arthrex, Tibial \& Femoral Opening Wedge Osteotomy System, Surgical Technique 2002.

7. Lobenhoffer P, Agneskirchner JD. Improvements in surgical technigue of valgus high tibial osteotomy. Knee Surg Sports 2003;11:132-8. Crossref

8. Esenkaya i. A new distractor with angle-scale for proximal tibia medial opening wedge osteotomy. Knee Surg Sports Traumatol Arthrosc 2006;14:443-6. Crossref

9. Esenkaya i. Proksimal tibia medial açık kama osteotomisi. TOTBID Derg 2005;4:1-14. http://www.totbid.org.tr/files/ ONLIB/4_1/2.pdf

10. Esenkaya i, Elmalı N. Proximal tibia medial open-wedge osteotomy using plates with wedges: early results in 58 cases. Knee Surg Sports Traumatol Arthrosc 2006;14:955-61. Crossref

11. Esenkaya i. Opening wedge proximal tibial osteotomy using the plate with wedge. Tech Knee Surg 2006;5:261-73. Crossref

12. Elmalı N, Esenkaya i. Proksimal tibia medial açık kama ostetomisi. Türkiye Klinikleri J Orthop \& Traumatol - Special Topics 2013;6:70-8.

13. Esenkaya I, Ünay K. Proksimal Tibia Mediyal Açık Kama Osteotomisi (Bölüm 6). İçinde: Sur H. editör. Yüksek Tibial Osteotomi. Ankara: TOTBíD Yayınları, BAYT; 2014. ss.49-62. 
14. Esenkaya i, Ünay K. Proximal medial tibial biplanar retrotubercle open wedge osteotomy in medial knee arthrosis. Knee 2012;19:416-21. Crossref

15. Elmalı N, Esenkaya I, Can M, Karakaplan M. Monoplanar versus biplanar medial open-wedge proximal tibial osteotomy for varus gonarthrosis: a comparison of clinical and radiological outcomes. Knee Surg Sports Traumatol Arthrosc 2013;21:2689-95. Crossref

16. Esenkaya i, Ünay K, Türkmen i. Medial gonartrozda retrotüberkül açık kama ostetomisi. Türkiye Klinikleri J Orthop \& Traumatol - Special Topics 2013;6:79-85.
17. Esenkaya I, Poyanlı O, Gökçen HB. İki planlı "Retrotüberkül” Medial Açık Kama Valgus Osteotomisi ve Kamalı Plak Uygulaması (Bölüm 14). İçinde: Esenkaya İ, Özenci M, Kocabey Y, Bombacı H, Köse Ö, editörler. Diz Çevresi Osteotomileri. İstanbul: İstanbul Tıp Kitapevleri; 2018. ss.115-25.

18. Esenkaya i, Özturan B. Proksimal tibia medial açık kama iki planlı retrotüberkül osteotomisi: kamalı plak ile tespit. TOTBID Derg 2020;19:399-408. Crossref

19. Tibia üst uç osteotomilerinde kullanılmak üzere bir tarafları künt uçlu osteotomlar. T.C. Türk Patent Enstitüsü. Faydalı Model Belgesi. No: TR 2007 02707. https://portal. turkpatent.gov.tr/anonim/arastirma/patent/detayli 